\title{
Influence of feeding level and of protein level in early life on the cellularity of adipose tissue and body fat content of growing pigs
}

\author{
BY R. G. CAMPBELL* AND A. C. DUNKIN \\ School of Agriculture and Forestry, University of Melbourne, Parkville, Victoria, 3052, \\ Australia
}

(Received 1 March 1982 - Accepted 26 July 1982)

1. The effects of level of feeding and level of protein in the early postnatal period on the cellularity of subcutaneous adipose tissue and body fat content of pigs were investigated in two experiments.

2. In Expt 1, piglets were given a common liquid diet at energy intakes equivalent to $2 \cdot 8$ or $5 \cdot 2$ times energy for maintenance $(\mathrm{M})$ between 1.8 and $6.5 \mathrm{~kg}$ live weight (LW), and a common dry diet at 2.8 or $4.5 \mathrm{M}$ between 6.5 and $20 \mathrm{~kg} \mathrm{LW}$. Between 20 and $75 \mathrm{~kg} \mathrm{LW}$ all pigs were given a second dry diet at $4.0 \mathrm{M}$.

3. In both experiments the effects of nutritional treatments on fat cell number at 20 and $75 \mathrm{~kg} \mathrm{LW}$ (Expt 1) and at $45 \mathrm{~kg} \mathrm{LW}$ (Expt 2) were assessed by measuring the DNA content of the subcutaneous adipose tissue contained in the left shoulder joint. Fat cell size was assessed in the same tissue by measuring the diameter of collagenase-released adipocytes.

4. In Expt 1, raising the level of feeding between 1.8 and $6.5 \mathrm{~kg} \mathrm{LW}$ increased body fat content and average fat cell diameter at both $6.5(P<0.01)$ and $20 \mathrm{~kg} \mathrm{LW}(P<0.05)$ but had no effect on either measurement at $75 \mathrm{~kg} \mathrm{LW}$. Similarly, raising the level of feeding between 6.5 and $20 \mathrm{~kg} \mathrm{LW}$ increased body fat content and fat cell size at both $20(P<0.01)$ and $75 \mathrm{~kg} \mathrm{LW}(P<0.05)$. There was an almost twofold increase in the DNA content of subcutaneous adipose tisuue between 20 and $75 \mathrm{~kg} \mathrm{LW}$. However, it was not significantly affected at either weight by level of feeding before or subsequent to $6.5 \mathrm{~kg} \mathrm{LW}$.

5. In Expt 2, reducing the level of dietary protein between 1.8 and $6.5 \mathrm{~kg} \mathrm{LW}$ increased body fat content $(P<0.01)$ and fat cell size $(P<0.01)$ at the latter weight. Although level of dietary protein to $6.5 \mathrm{~kg} \mathrm{LW} \mathrm{had}$ no effect on body fat content or the weight of subcutaneous adipose tissue in the shoulder joint at $45 \mathrm{~kg} \mathrm{LW}$, pigs given the lowest-protein diet contained less DNA $(P<0.05)$ in the subcutaneous adipose tissue and had larger $(P<0.05)$ fat cells than those given the highest-protein diet to $6.5 \mathrm{~kg} \mathrm{LW}$. Reducing the protein content of the diet fed subsequent to $6.5 \mathrm{~kg} \mathrm{LW}$ increased the body fat content $(P<0.01)$ and fat cell size $(P<0.01)$ at $45 \mathrm{~kg}$ LW.

Experimental evidence with rats has suggested that 'overfeeding' in the early postnatal period stimulates the proliferation of adipocytes, which, in turn, predisposes to obesity in later life (Knittle \& Hirsch, 1968; Hirsch \& Knittle, 1970; Oscai et al. 1972, 1974). However, in all these studies the animals were compared at constant age but at widely differing body-weights. Consequently the conclusions drawn from the results of these studies may be misleading, particularly as the results of Lee et al. $(1973 a, b)$ showed that, although manipulation of feed intake in early life had a marked effect on fat cell number, when comparisons were at constant age no differences were apparent when animals were compared at constant weight.

For the pig, Lee et al. $(1973 a, b)$ suggested that the hyperplasic development of subcutaneous adipose tissue was complete before birth and was therefore unaffected by level of feeding in the postnatal period. On the other hand, the more recent findings of Hood \& Allen (1977) and Wood et al. (1978) indicate a continual increase in porcine adipocites to at least $188 \mathrm{~d}$ of age. Nevertheless, these latter experiments provide no information on how the cellularity of adipose tissue is influenced by the level of feeding in early life. There is also little information on the effects of either the duration of feed restriction or the stage of development in which it is imposed, on the cellularity of adipose tissue or the development of body fat in later life.

* Present address: Animal Research Institute, Princes Highway, Werribee, Victoria, 3030, Australia. 
Although nutritional obsesity in the young animal is more readily created by protein deprivation than by high levels of feeding (Black, 1974), there is little information as to the effects of protein nutrition in early life on the cellularity of adipose tissue or on subsequent fat development.

The two experiments reported here were designed to study the effects of level of feeding (Expt 1) and protein nutrition (Expt 2) in early life on the cellular development of subcutaneous adipose tissue and on the body fat content of pigs grown to 75 and $45 \mathrm{~kg}$ live weight (LW) respectively.

Because of the inaccuracies involved with the Coulter Counter technique for counting and sizing adipocytes from young and energy-restricted animals (Hood, 1977), fat cell number and size were estimated by measuring the DNA content of fat samples and the diameters of collagenase-released adipocytes respectively.

\section{EXPERIMENT A L}

Animals and design

In both experiments, Large White piglets were removed from their dams within $24 \mathrm{~h}$ of birth. The initial experimental treatments were introduced as individual piglets reached $1.8 \mathrm{~kg} \mathrm{LW}$ and were maintained until $6.5 \mathrm{~kg} \mathrm{LW}$.

In Expt 1, a total of thirty-eight piglets, representing entire males and females, were allocated to either a low or high level of feeding of a common diet to $6.5 \mathrm{~kg} \mathrm{LW}$ when three pigs, selected randomly at $1.8 \mathrm{~kg} \mathrm{LW}$, were killed from each treatment group. The remaining pigs were allocated to a low or high level of feeding of a second diet to $20 \mathrm{~kg} \mathrm{LW}$ when three pigs, selected at $6.5 \mathrm{~kg} \mathrm{LW}$, were killed from each treatment group (total of twelve pigs killed at $20 \mathrm{~kg}$ ). The remaining animals were given a third diet at approximately four times the energy requirement for maintenance $(M)$ and were killed at $75 \mathrm{~kg} \mathrm{LW}$. Subsequent to $6.5 \mathrm{~kg} \mathrm{LW}$, the results were analysed as a $2 \times 2$ factorial experimental design with eight and five replicates per treatment between 6.5 and $20 \mathrm{~kg} \mathrm{LW}$ and between 20 and $75 \mathrm{~kg} \mathrm{LW}$ respectively. The respective factors were level of feeding beteen 1.8 and $6.5 \mathrm{~kg}$ LW (low and high) and level of feeding between 6.5 and $20 \mathrm{~kg} \mathrm{LW}$ (low and high). All treatment groups were balanced equally for sex.

In Expt 2, a total of forty-five piglets, representing entire males and females were allocated among three dietary treatments comprising low-, medium- and high-protein diets to $6.5 \mathrm{~kg}$ LW. At the latter weight three piglets chosen randomly at $1.8 \mathrm{~kg} \mathrm{LW}$ were killed from each treatment group. The remaining pigs were reallocated among a low- or high-protein treatment. At $6.5 \mathrm{~kg} \mathrm{LW}$ two pigs from each treatment group were selected and later killed at $11.5 \mathrm{~kg} \mathrm{LW}$ (total of twelve piglets); the remainder were killed at $45 \mathrm{~kg} \mathrm{LW}$ (total of thirty pigs). The results subsequent to $6.5 \mathrm{~kg}$ were analysed as a $3 \times 2$ factorial experiment with six and four replicates per treatment between 6.5 and $11.5 \mathrm{~kg}$ and 6.5 and $45 \mathrm{~kg} \mathrm{LW}$ respectively. The respective factors were dietary protein content from 1.8 to $6.5 \mathrm{~kg} \mathrm{LW}$ (low, medium and high) and level of dietary protein from 6.5 to $45 \mathrm{~kg} \mathrm{LW}$ (low and high).

\section{Diets and feeding}

The composition and analysis of the diets used in Expts 1 and 2 are given in Tables 1 and 2 respectively. Liquid diets were given from 1.8 to $6.5 \mathrm{~kg} \mathrm{LW}$ in Expt 1 and from 1.8 to $11.5 \mathrm{~kg} \mathrm{LW}$ in Expt 2.

In Expt 1, the liquid diet contained $200 \mathrm{~g}$ total solids $/ \mathrm{kg}$ and $13.7 \mathrm{~g}$ crude protein $(\mathrm{CP}$, nitrogen $\times 6.38) / \mathrm{MJ}$ gross energy $(\mathrm{GE})$. The relative amounts of protein and energy were selected to be slightly in excess of the requirements previously determined (Williams, 1976) for pigs growing over the same $\mathrm{LW}$ range and diets based on similar ingredients. The low and high levels of feeding to $6.5 \mathrm{~kg}$ provided GE intakes of 1.42 and $1.62 \mathrm{MJ} / \mathrm{kg} \mathrm{LW}^{0.75}$ per $\mathrm{d}$, or $2 \cdot 8$ and $5 \cdot 2 \mathrm{M}$ respectively. 
Table 1. Expt 1. Composition of diets

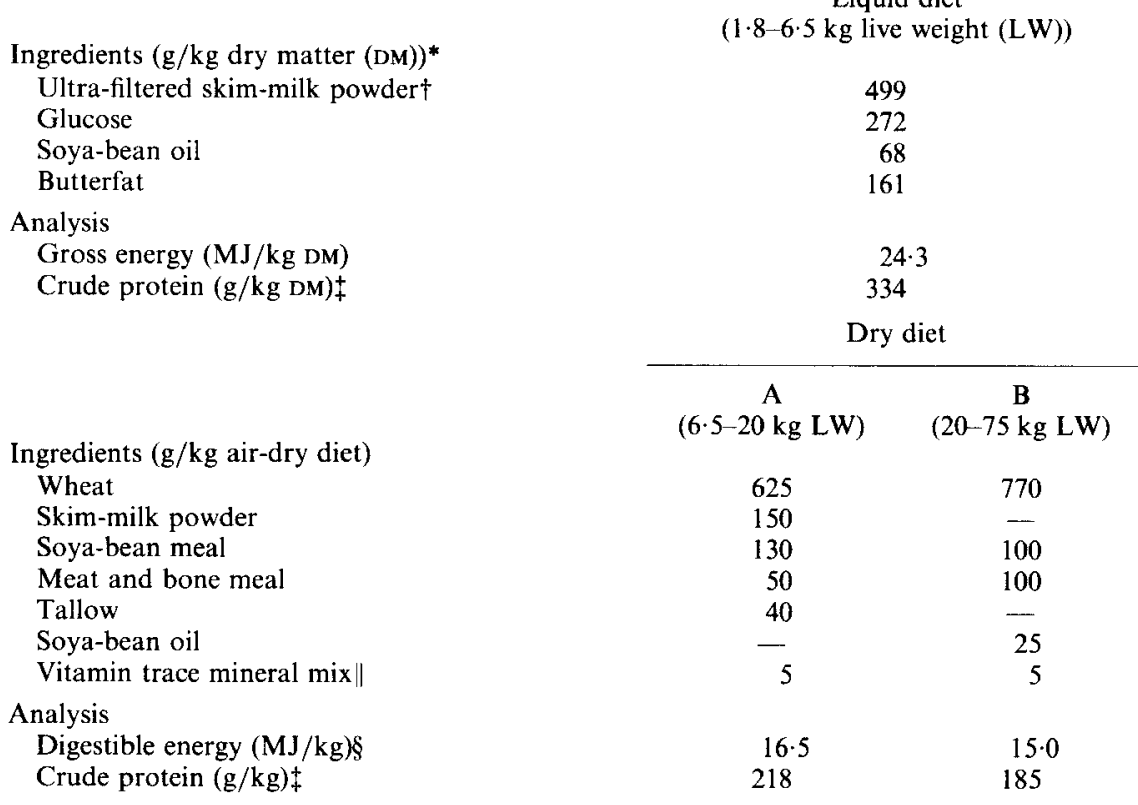

* Reconstituted with water to $200 \mathrm{~g}$ total solids $/ \mathrm{kg}$. The following micro-nutrients were added daily before feeding $(\mathrm{mg} /$ pig per $\mathrm{d}$ ): cholecalciferol $0 \cdot 12$, D- $\alpha$-tocopherol $31 \cdot 0$, retinol $0 \cdot 85$, menadione $0 \cdot 06$, thiamin $1 \cdot 50$, riboflavin $2 \cdot 50$, nicotinic acid $20 \cdot 0$, pantothenic acid $10 \cdot 00$, pyridoxine $2 \cdot 50$, cyanocobalamin $0 \cdot 02$, biotin $0 \cdot 08$, pteroylmonoglutamic acid 1.00, ascorbic acid $100 \cdot 0$, iron $20 \cdot 0$, zinc $10 \cdot 0$, manganese $4 \cdot 0$, copper $2 \cdot 0$.

$\dagger$ Prepared by the continual circulation of raw skim-milk in contact with a semi-permeable membrane for $3 \mathrm{~h}$ at $55^{\circ}$ and by spray drying.

$\ddagger \mathrm{N} \times 6 \cdot 38$.

If Provided the following nutrients $(\mathrm{mg} / \mathrm{kg}$ air-dry diet): retinol $6 \cdot 4$, cholecalciferol $8 \cdot 3$, menadione 660 , riboflavin $3 \cdot 3, \mathrm{D}-\alpha$-tocopherol 22 , nicotinic acid $16 \cdot 5$, pantothenic acid $5 \cdot 5$, pyridoxine $1 \cdot 1$, cyanocobalamin 17 , biotin 56 , choline 1110 , iron 88 , zinc 55 , manganese 22 , copper $6 \cdot 6$, iodine $0 \cdot 22$, selenium $0 \cdot 1$.

$\S$ Determined in metabolism trials.

The wheat-based diet given to pigs from 6.5 to $20 \mathrm{~kg} \mathrm{LW}$ (diet A, Table 1) contained 16.5 MJ digestible energy (DE) and $218 \mathrm{~g} \mathrm{CP} / \mathrm{kg}$. The low and high levels of feeding used during this phase provided 1.4 and $2.3 \mathrm{MJ} \mathrm{DE} / \mathrm{kg} \mathrm{LW}^{\mathbf{2} 75}$ per $\mathrm{d}$, or 2.8 and $4.5 \mathrm{M}$ respectively. Between 20 and $75 \mathrm{~kg} \mathrm{LW}$ (diet B, Table 1) was given according to a scale which provided $1.92 \mathrm{MJ} \mathrm{DE} / \mathrm{kg} \mathrm{LW}^{0.75}$ per $\mathrm{d}$, or $4.0 \mathrm{M}$.

In Expt 2, the low-, medium- and high-protein diets used between 1.8 and $6.5 \mathrm{~kg} \mathrm{LW}$ contained $24 \mathrm{MJ}$ GE $/ \mathrm{kg}$ dry matter (DM) and 153,240 and $320 \mathrm{~g} \mathrm{CP} / \mathrm{kg}$ DM respectively. All diets were given at the same level (2.0 MJ GE/ $\mathrm{kg} \mathrm{LW}^{0.75}$ per d). The low- and high-protein liquid diets used between 6.5 and $11.5 \mathrm{~kg} \mathrm{LW}$ contained approximately $24 \mathrm{MJ} \mathrm{GE} / \mathrm{kg} \mathrm{DM}$ and 150 and $250 \mathrm{~g} \mathrm{CP} / \mathrm{kg}$ DM respectively. From $11.5 \mathrm{~kg} \mathrm{LW}$ wheat-based diets (diets D and $\mathrm{E}$, Table 2), equalized for DM content and containing 150 and $210 \mathrm{~g} \mathrm{CP} / \mathrm{kg}$ respectively, were fed. Feeding subsequent to $6.5 \mathrm{~kg} \mathrm{LW}$ was at the rate of $1.64 \mathrm{MJ} \mathrm{DE} / \mathrm{kg} \mathrm{LW}$. $^{0.75}$ per d.

\section{Feeding management}

Between weaning and the commencement of the experimental treatments at $1.8 \mathrm{~kg}$, all pigs were given a liquid diet containing $24 \mathrm{MJ}$ GE $/ \mathrm{kg}$ DM and $290 \mathrm{~g} \mathrm{CP} / \mathrm{kg}$ DM. The level of feed offered during this period was equivalent to $1.5 \mathrm{MJ} \mathrm{GE} / \mathrm{kg} \mathrm{LW}^{0 \cdot 75}$ per d.

Initially, piglets were taught to drink from an infant's bottle and, later, from teats fixed 
Table 2. Expt 2. Composition of diets

\begin{tabular}{|c|c|c|c|c|c|}
\hline & \multicolumn{5}{|c|}{ Liquid diet } \\
\hline & \multicolumn{3}{|c|}{$(6.5 \mathrm{~kg}$ live weight $(\mathrm{LW}))$} & \multicolumn{2}{|c|}{$(6.5-11.5 \mathrm{~kg} \mathrm{LW})$} \\
\hline & $\mathrm{A}$ & B & $\mathrm{C}$ & $\mathrm{D}$ & $\mathrm{E}$ \\
\hline \multicolumn{6}{|l|}{ Ingredients $(\mathrm{g} / \mathrm{kg} \text { dry matter }(\mathrm{DM}))^{*}$} \\
\hline Ultra-filtered skim-milk powder $\dagger$ & 250 & 368 & 478 & - & - \\
\hline Skim-milk powder & - & - & - & 415 & 678 \\
\hline Glucose & 407 & 344 & 291 & 304 & 150 \\
\hline Soya-bean oil & 77 & 68 & 60 & 60 & 39 \\
\hline Butterfat & 233 & 207 & 171 & 192 & 133 \\
\hline Mineral mix & 33 & 13 & - & 29 & \\
\hline \multicolumn{6}{|l|}{ Analysis } \\
\hline Gross energy ( $\mathrm{M} J / \mathrm{kg}$ DM) & $24 \cdot 0$ & $23 \cdot 9$ & $23 \cdot 8$ & $23 \cdot 8$ & $24 \cdot 2$ \\
\hline \multirow[t]{3}{*}{ Crude protein $(\mathrm{g} / \mathrm{kg} \mathrm{DM})$} & 153 & 239 & 321 & 151 & 252 \\
\hline & \multicolumn{5}{|c|}{ Dry diet $(11 \cdot 5-45 \mathrm{~kg} \mathrm{LW})$} \\
\hline & & $\mathrm{D}_{1}$ & & $E_{1}$ & \\
\hline \multicolumn{6}{|l|}{ Ingredients ( $\mathrm{g} / \mathrm{kg}$ air-dry diet) } \\
\hline Wheat & \multicolumn{3}{|c|}{480} & \multicolumn{2}{|c|}{640} \\
\hline Wheaten starch & \multicolumn{3}{|c|}{243} & \multicolumn{2}{|l|}{-} \\
\hline Skim-milk powder & \multicolumn{3}{|c|}{96} & \multicolumn{2}{|c|}{128} \\
\hline Soya-bean meal & \multicolumn{3}{|c|}{103} & \multicolumn{2}{|c|}{138} \\
\hline Meat and bone meal & \multicolumn{3}{|c|}{52} & \multicolumn{2}{|c|}{69} \\
\hline Soya-bean oil & \multicolumn{3}{|c|}{14} & \multicolumn{2}{|c|}{20} \\
\hline Tricalcium phosphate & \multicolumn{3}{|c|}{7} & \multicolumn{2}{|c|}{ - } \\
\hline Vitamin trace mineral mix $\S$ & \multicolumn{3}{|c|}{5} & \multicolumn{2}{|c|}{5} \\
\hline \multicolumn{6}{|l|}{ Analysis } \\
\hline Digestible energy $(\mathrm{MJ} / \mathrm{kg})$ & \multicolumn{3}{|c|}{15.9} & \multicolumn{2}{|c|}{$15 \cdot 7$} \\
\hline Crude protein $(\mathrm{g} / \mathrm{kg})$ & \multicolumn{3}{|c|}{150} & \multicolumn{2}{|c|}{210} \\
\hline
\end{tabular}

* Reconstituted with water to $200 \mathrm{~g}$ total solids $/ \mathrm{kg}$. The vitamin-mineral mixture was added daily before feeding and supplied (mg/pig per d): cholecalciferol $0.12, \mathrm{D}-\alpha$-tocopherol $31 \cdot 0$, retinol 0.85 , menadione 0.06 , thiamin $1 \cdot 50$, riboflavin $2 \cdot 50$, nicotinic acid $20 \cdot 0$, pantothenic acid $10 \cdot 0$, pyridoxine $2 \cdot 50$, cyanocobalamin $0 \cdot 02$, biotin $0 \cdot 08$, pteroylmonoglutamic acid $1 \cdot 00$, ascorbic acid $100 \cdot 0$, iron $20 \cdot 0$, zinc $10 \cdot 0$ manganese $4 \cdot 0$, copper $2 \cdot 0$.

$\dagger$ Prepared by the continual circulation of raw skim-milk in contact with a semi-permeable membrane for $3 \mathrm{~h}$ at $55^{\circ}$ and by spray drying.

$\ddagger$ Contained the following compounds $(\mathrm{g} / \mathrm{kg}$ ) (excluding water of hydration): calcium lactate 608 , $\mathrm{Na}_{2} \mathrm{HPO}_{4} .12 \mathrm{H}_{2} \mathrm{O} 153, \mathrm{KH}_{2} \mathrm{PO}_{4} 222, \mathrm{MgSO}_{4} .7 \mathrm{H}_{2} \mathrm{O} 17$.

II $\mathrm{N} \times 6.38$

$\S$ Provided the following nutrients ( $\mathrm{mg} / \mathrm{kg}$ air-dry diet): retinol $6 \cdot 4$, cholecalciferol $8 \cdot 3$, menadione 660 , riboflavin $3 \cdot 3, \mathrm{D}-\alpha$-tocopherol 22 , nicotinic acid $16 \cdot 5$, pantothenic acid $5 \cdot 5$, pyridoxine $1 \cdot 1$, cyanocobalamin 17 , biotin 56 , choline 1110 , iron 88 , zinc 55 , manganese 22 , copper $6 \cdot 6$, iodine $0 \cdot 22$, selenium $0 \cdot 1$.

- Determined in metabolism trials.

to the side of each cage and connected by plastic tubing to a reservoir of milk located below the level of the teat. During this training period, which lasted from 6 to $24 \mathrm{~h}$, feed was offered every hour. This was followed by thrice daily feeding to $3 \mathrm{~d}$ of age and by twice daily feeding at 08.00 and $16.00 \mathrm{~h}$ thereafter.

Liquid diets were prepared by mixing the milk powder and glucose in warm water. The butterfat and soya-bean oil were heated and incorporated into the diets by homogenization. Formalin $(1 \mathrm{ml} / \mathrm{l})$ was added to the diets immediately after mixing and they were stored at $4^{\circ}$ until fed.

Vitamins and trace minerals were added daily to the liquid diets before feeding. The levels given (see Table 1) were based on the estimates of requirements given by the Agricultural Research Council (1967). Because of the low levels of milk powder contained in the 
lower-protein diets given to pigs of $11.5 \mathrm{~kg} \mathrm{LW}$ in Expt 2, extra calcium and phosphorus were added in accordance with the levels recommended by the Agricultural Research Council (1967).

\section{Housing and management}

Between weaning and $6.5 \mathrm{~kg} \mathrm{LW}($ Expt 1) or $11.5 \mathrm{~kg} \mathrm{LW}$ (Expt 2) the piglets were housed in individual wire mesh cages $(0.6 \times 0.45 \times 0.52 \mathrm{~m}$ high) in an insulated room which was maintained at a temperature of $30^{\circ}$ for the first week of each experiment and at $25^{\circ}$ thereafter. During these periods, the pigs were weighed daily and each pig's feed allowance for the following day was adjusted accordingly. At the completion of the milk-feeding stage of each experiment, pigs were transferred to individual pens in an insulated building which was maintained at a temperature of $21^{\circ}$.

\section{Post-slaughter procedures}

Immediately after slaughter, a section of subcutaneous adipose tissue was removed from directly above the first thoracic vertebra of all pigs except those killed at $11.5 \mathrm{~kg} \mathrm{LW}$ in Expt 2. This was divided into two equal portions. One portion was prepared immediately for fat cell size determinations, the other was stored at $-30^{\circ}$ for subsequent DNA analysis.

The contents of the gastrointestinal tract were removed and for pigs killed at $6.5 \mathrm{~kg} \mathrm{LW}$ in Expt 1 and at 6.5 and $11.5 \mathrm{~kg} \mathrm{LW}$ in Expt 2 the eviscerated carcass, blood, internal organs and empty gut were weighed and stored together at $-20^{\circ}$. A similar procedure was adopted for pigs killed at heavier weights in both experiments except that only the right side of each carcass was used for chemical analysis and this was stored and prepared separately from the blood, empty gut and internal organs. The head and shoulder joints were also removed from the left side of each carcass by transverse cuts passing between the atlas and occipital processes and between the second and third thoracic vertebrae respectively. The subcutaneous adipose tissue in the sholder joint was dissected out and weighed.

\section{Chemical analysis}

For DM determinations, milk powders and glucose were dried at $70^{\circ}$ for $72 \mathrm{~h}$; the liquid diets were first freeze-dried to constant weight. For the dry diets and carcass material, DM was determined by drying samples to constant weight at $105^{\circ}$.

Protein $(\mathrm{N} \times 6.38)$ was determined on air-dry samples of the dry diets and on feeze-dried samples of liquid diets by Kjeldahl analysis. Body fat was determined by extracting freeze-dried samples in chloroform-methanol $(2: 1, \mathrm{v} / \mathrm{v})$ for $8 \mathrm{~h}$ and drying the extract to constant weight (Braude \& Newport, 1973).

\section{Cellularity measurements}

The DNA content of subcutaneous adipose tissue from pigs killed at 20 and $75 \mathrm{~kg} \mathrm{LW}$ in Expt 1 and at $45 \mathrm{~kg} \mathrm{LW}$ in Expt 2 was determined using the method of Martin \& Donohue (1972) following extraction of lipid from the samples by shaking in cold chloroform-methanol $(2: 1, v / v)$ for 4-5 min. The total DNA content of the subcutaneous adipose tissue in the left shoulder joint was calculated as weight of dissected tissue $(\mathrm{g}) \times$ DNA concentration of tissue $(\mathrm{mg} / \mathrm{g})$. Although the DNA method for assessing fat cell number includes an unknown amount of DNA from cells other than adipocytes, we considered the technique more appropriate for assessing the qualitative effect of nutrition on fat cell number than either the Coulter counter method, which under-estimates fat cell number in young and energy-restricted animals (Hood, 1977) or any of the microscopic techniques, which only enable observable adipocytes to be counted (Gurr \& Kirtland, 1978).

Average fat cell diameter was determined by measuring the maximum diameters of 300 
R. G. Campbell and A. C. Dunkin

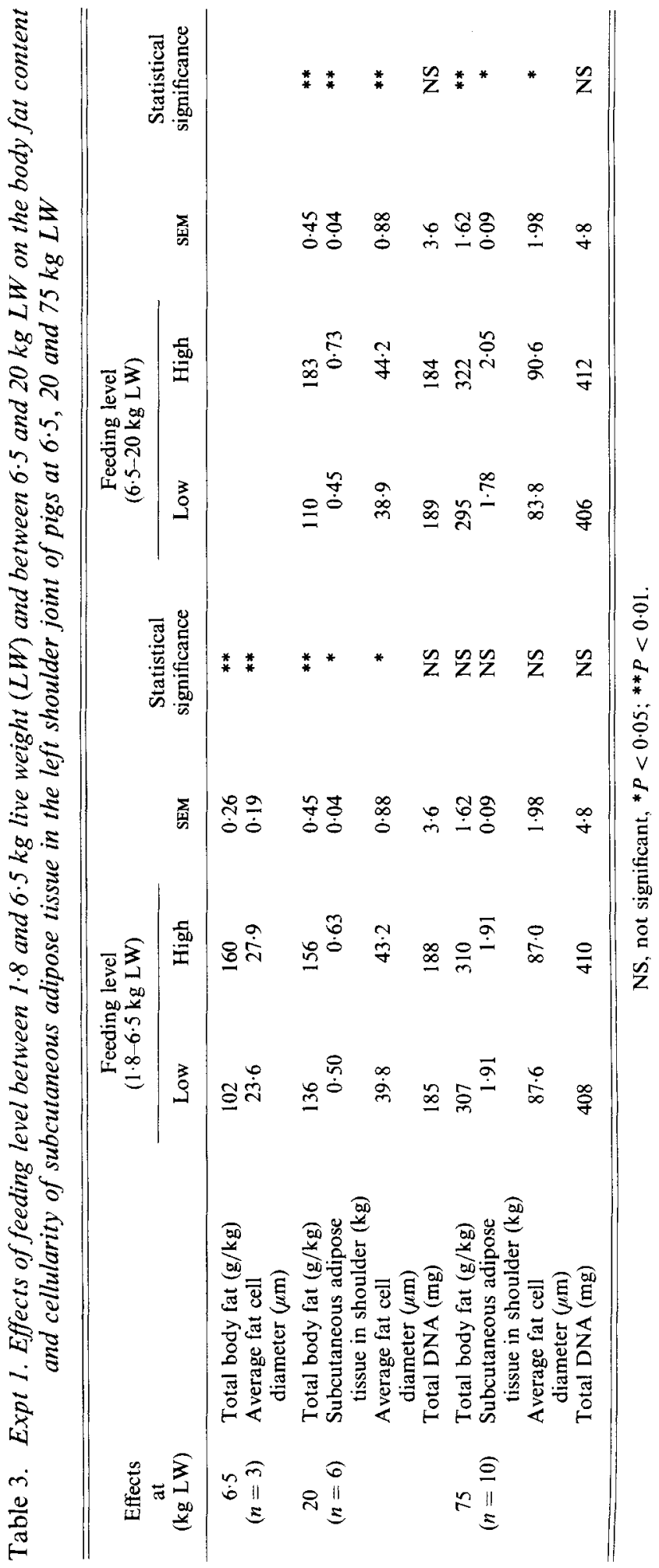


Table 4. Expt 2. Effects of dietary protein level between 1.8 and $6.5 \mathrm{~kg}$ and between 6.5 and $45 \mathrm{~kg}$ on the body fat content and cellularity of subcutaneous adipose tissue in the left shoulder joint of pigs at $6.5,11.5$ and $45 \mathrm{~kg}$ live weight $(\mathrm{LW})$

\begin{tabular}{|c|c|c|c|c|c|c|c|c|c|}
\hline \multirow{2}{*}{\multicolumn{2}{|c|}{$\begin{array}{c}\text { Effects } \\
\text { at } \\
(\mathrm{kg} \mathrm{LW})\end{array}$}} & \multicolumn{3}{|c|}{$\begin{array}{c}\text { Dietary protein level } \dagger \\
1.8-6.5 \mathrm{~kg}\end{array}$} & \multirow[b]{2}{*}{ SEM } & \multicolumn{2}{|c|}{$\begin{array}{l}\text { ietary protein level } \neq \\
6.5-45 \mathrm{~kg}\end{array}$} & \multirow[b]{2}{*}{ SEM } & \multirow{2}{*}{$\begin{array}{l}\text { Statistical } \\
\text { significance }\end{array}$} \\
\hline & & Low & Medium & High & & Low & High & & \\
\hline \multirow[t]{2}{*}{$6 \cdot 5$} & Total body fat $(\mathrm{g} / \mathrm{kg})$ & $190_{\mathrm{a}}$ & $138_{\mathrm{b}}$ & $120_{\mathrm{c}}$ & 0.97 & & & & \\
\hline & $\begin{array}{l}\text { Average fat cell } \\
\text { diameter }(\mu \mathrm{m})\end{array}$ & $42 \cdot 6_{a}$ & $38 \cdot 8_{\mathrm{ab}}$ & $35 \cdot 2_{b}$ & 0.93 & & & & \\
\hline $11 \cdot 58$ & Total body fat $(\mathrm{g} / \mathrm{kg})$ & $188_{\mathrm{a}}$ & $152_{\mathrm{b}}$ & $155_{b}$ & 1.51 & 192 & 137 & 1.23 & $* *$ \\
\hline \multirow[t]{4}{*}{45} & Total body fat $(\mathrm{g} / \mathrm{kg})$ & $181^{\mathrm{a}}$ & $177^{\mathrm{a}}$ & $184^{a}$ & 1.60 & 209 & 153 & 1.29 & ** \\
\hline & $\begin{array}{l}\text { Subcutaneous adipose } \\
\text { tissue in shoulder }(\mathrm{kg})\end{array}$ & $0.78^{\mathrm{a}}$ & $0.76^{\mathrm{a}}$ & $0.78^{\mathrm{a}}$ & 0.04 & 0.89 & 0.66 & 0.03 & $* *$ \\
\hline & $\begin{array}{l}\text { Average fat cell } \\
\text { diameter }(\mu \mathrm{m})\end{array}$ & $69 \cdot 3^{\mathrm{a}}$ & $65 \cdot 2^{\mathrm{ab}}$ & $63 \cdot 4^{b}$ & 1.65 & $70 \cdot 6$ & $62 \cdot 6$ & $1 \cdot 30$ & $* *$ \\
\hline & Total DNA (mg) & $229^{\mathrm{a}}$ & $251^{\mathrm{ab}}$ & $265^{b}$ & $9 \cdot 7$ & 235 & 257 & 7.9 & NS \\
\hline
\end{tabular}

a,b,c Within rows, treatment means followed by different subscript letters differ significantly $(P<0.01)$. Treatment means followed by different superscript letters differ significantly $(P<0.05)$.

NS, not significant, $* * P<0.01$.

$\dagger$ Results at $6.5,11.5$ and $45 \mathrm{~kg} \mathrm{LW}$ based on three, four and eight pigs/treatment respectively.

$\ddagger$ Results at 11.5 and $45 \mathrm{~kg} \mathrm{LW}$ based on six and twelve pigs/treatment mean respectively.

$\$$ Only body fat content assessed at $11.5 \mathrm{~kg}$.

consecutive adipocytes from duplicated samples of adipose tissue from each pig with a Wild photomicroscope (magnification $\times 200$ ) using a slight modification of the collagenase method of Smith et al. (1972). The technique involved incubating thin slices of adipose tissue $\left(0.6-0.8 \mathrm{~g}\right.$ total weight) at $39^{\circ}$ for $90 \mathrm{~min}$ in an isotonic solution containing $7 \mathrm{mg}$ collagenase (type 1 , lot $86 \mathrm{C} \cdot 0258$, Sigma, St. Lousis, Missouri). Using a plastic pipette, $0.25 \mathrm{ml}$ of the final cell suspension was removed and placed in a plastic cylinder and covered with a coverslip. This technique resulted in an almost complete release of adipocytes and no cell disruption was observed during cell sizing. However, in a series of preliminary investigations of the collagenase method, considerable dissolution of larger adipocytes was observed in cell preparations from incubation solutions which contained more than $11 \mathrm{mg}$ collagenase (Campbell, 1981). This effect, which appears to be associated with proteinase activity in most collagenase preparations, has also been observed in studies with human fat cells (Salans et al. 1968).

\section{Statistical analysis}

Treatment effects were assessed by analysis of variance and a posteriori comparisons were made between all treatment means using Duncan's multiple range test (Duncan, 1955).

\section{RESULTS}

There were no significant interactions between the effects of nutrition prior and subsequent to $6.5 \mathrm{~kg} \mathrm{LW}$ for body fat content, total DNA or average fat cell diameter in either experiment. The results for Expts 1 and 2 are presented in Tables 3 and 4 respectively.

In Expt 1, raising the level of feeding, between 1.8 and $6.5 \mathrm{~kg} \mathrm{LW}$, from 1.42 to $2.62 \mathrm{MJ}$ $\mathrm{GE} / \mathrm{kg} \mathrm{LW} \mathrm{L}^{0.75}$ per $\mathrm{d}$ increased body fat content and average fat cell diameter at both 6.5 $(P<0.01)$ and $20 \mathrm{~kg} \mathrm{LW}(P<0.05)$ but had no effect on either measurement at $75 \mathrm{~kg} \mathrm{LW}$. 
Similarly, raising the level of feeding, between 6.5 and $20 \mathrm{~kg} \mathrm{LW}$, from 1.4 to $2.25 \mathrm{MJ}$ $\mathrm{DE} / \mathrm{kg} \mathrm{LW}^{0.75}$ per $\mathrm{d}$ increased body fat content, the weight of subcutaneous adipose tissue in the shoulder joint and average fat cell diameter at both $20(P<0.01)$ and $75 \mathrm{~kg} \mathrm{LW}$ $(P<0 \cdot 05)$. Between 20 and $75 \mathrm{~kg} \mathrm{LW}$ there was a marked increase in the total DNA content of the subcutaneous adipose tissue in the shoulder joint. The latter, however, was unaffected by level of feeding before and subsequent to $6.5 \mathrm{~kg} \mathrm{LW}$.

In Expt 2, each decrease in the level of dietary protein between 1.8 and $6.5 \mathrm{~kg} \mathrm{LW}$ increased $(P<0.01)$ body fat at the latter weight. Pigs given the lowest-protein diet also contained larger fat cells $(P<0.01)$ than those given the diet of highest-protein content. Although there was $30 \%$ difference $(P<0.01)$ in body fat at $11.5 \mathrm{~kg} \mathrm{LW}$ between pigs given the lowest- and highest-protein diets before $6.5 \mathrm{~kg} \mathrm{LW}$, the differences in total body fat and the weight of subcutaneous fat in the shoulder joint at $45 \mathrm{~kg} \mathrm{LW}$ were not significantly different between the three initial protein treatments. However, within the subcutaneous adipose tissue, pigs given the lowest-protein diet from 1.8 to $6.5 \mathrm{~kg} \mathrm{LW}$ contained less DNA $(P<0.05)$ and had larger $(P<0.05)$ fat cells than those given the diet of highest protein content before $6.5 \mathrm{~kg} \mathrm{LW}$.

Reducing the protein content of the diet given subsequent to $6.5 \mathrm{~kg} \mathrm{LW}$ increased total body fat $(P<0.01)$, the weight of subcutaneous fat in the shoulder joint $(P<0.01)$ and average fat cell size $(P<0.01)$.

\section{DISCUSSION}

The results of these experiments showed that body fat at $6.5 \mathrm{~kg} \mathrm{LW}$ was markedly affected both by level of feeding and by level of dietary protein in the early postnatal period.

In Expt 1, raising the level of feeding between 1.8 and $6.5 \mathrm{~kg} \mathrm{LW}$, from approximately 2.8 to 5.2 times energy for maintenance increased body fat content at $6.5 \mathrm{~kg} \mathrm{LW}$ by $56 \%$. The difference had been reduced to $14.7 \%$ at $20 \mathrm{~kg} \mathrm{LW}$ and had disappeared by $75 \mathrm{~kg} \mathrm{LW}$. The results for DNA content of subcutaneous adipose tissue in the shoulder at $20 \mathrm{~kg}$ provided no evidence that fat cell number had been influenced by feeding level before $6.5 \mathrm{~kg} \mathrm{LW}$. On the other hand the results for fat cell size, both at 6.5 and $20 \mathrm{~kg} \mathrm{LW}$, suggested that the extra fat accumulated by pigs fed at the higher level in the early period was accommodated by an increase entirely in fat cell size.

Similarly, raising the level of feeding during the $6 \cdot 5-20 \mathrm{~kg} \mathrm{LW}$ period increased body fat content and fat cell size at both 20 and $75 \mathrm{~kg} \mathrm{LW}$ but, again, had no effect on fat cell number as assessed by DNA. These results are in agreement with those of a previous experiment (Campbell \& Dunkin, 1980) in which raising the level of feeding, between 1.8 and $6.5 \mathrm{~kg}$ LW, from approximately 1.8 to 4.5 times energy for maintenance, increased body fat and average fat cell diameter at the latter weight by 180 and $39 \%$ respectively but had no effect on fat cell number. Similar findings have also been reported by Lee et al. $(1973 a, b)$, although they suggested that the hyperplasic development of porcine adipose tissue was complete before birth and, as such, was unaffected by postnatal nutrition. More recently however, Hood \& Allen (1977) and Wood et al. (1978) reported a coutinual increase in the number of observable adipocytes in porcine adipose to at least $188 \mathrm{~d}$ of age. Kirtland \& Gurr (1980), using the incorporation of radiolabelled thymidine into fat cell DNA as an index of cell division, also reported rapid fat cell synthesis in pigs beween 2 and $40 \mathrm{~d}$ of age. The marked increase in DNA in subcutaneous adipose tissue between 20 and $75 \mathrm{~kg} \mathrm{LW}$ observed in the present experiment also supports the view that hyperplasia in porcine adipose tissue is not limited to prenatal or early postnatal development.

The results of the second experiment showed that reducing the level of protein in the period $1.8-6.5 \mathrm{~kg}$ increased the body fat content at 6.5 and $11.5 \mathrm{~kg} \mathrm{LW}$, but that these differences were no longer apparent at $45 \mathrm{~kg} \mathrm{LW}$. Nevertheless, the values for adipose 
cellularity at $45 \mathrm{~kg} \mathrm{LW}$ indicated that pigs given the lowest-protein diet before $6.5 \mathrm{~kg} \mathrm{LW}$ contained fewer, but larger, adipocytes than those given the highest-protein diet initially. It appears, therefore, that restricting protein intake in the early period retarded the hyperplasic development of subcutaneous adipose tissue and, on the basis of DNA measurements at $45 \mathrm{~kg} \mathrm{LW}$, indicated that the fattest pigs at $6.5 \mathrm{~kg} \mathrm{LW}$ probably contained the least number of adipocytes. Presumably, therefore, the marked increase in fat cell size at $6.5 \mathrm{~kg} \mathrm{LW}$ which was associated with decreasing dietary protein was the net effect of these animals having to accommodate more fat into fewer cells than pigs given the higher-protein diets. On the other hand, the greater fat cell size exhibited at $45 \mathrm{~kg} \mathrm{LW}$ by pigs given the lowest-protein diet before $6.5 \mathrm{~kg} \mathrm{LW}$ would appear to be a result of these animals having to accommodate the same amount of fat into fewer cells than those given the highest-protein diet initially. These latter results also suggest that, used in conjunction with a measure of fat-cell diameter, the DNA method is probably a valid technique for assessing the relative effects of different nutritional practices on fat-cell number of porcine adipose tissue. Nevertheless, because the method determines DNA from all cells present in adipose tissue, the values for total DNA presented here are undoubtedly an over-estimate of true fat cell number.

Protein deprivation in early life has also been reported to retard the hyperplasic development of muscle tissue in the rat (Winick \& Noble, 1967), chicken (Moss, 1968) as well as in the pig (Campbell \& Dunkin, 1980). Knittle (1972) also reported that rats reared on dams subjected to a protein restriction during lactation contained fewer adipocytes at both 6 and 12 weeks of age than rats reared on dams given a protein-adequate diet during lactation.

Our results do not support the generally held belief that nutritionally-induced obesity in the young rat (Knittle \& Hirsch, 1968; Bertrand \& Masoro, 1977) and human (Brook, 1972) is associated with an increase in fat cell number and that obesity in later life may be combatted by restricting the proliferation of adipocytes during infancy. However, in the previously-cited studies with rats, the animals were compared at widely-different bodyweights and, furthermore, at different stages of development. Thus, the conclusions drawn from these findings may be misleading.

Overall, our findings indicate a great elasticity in size of porcine adipocytes and suggest that fat cell number has little effect on the animal's propensity for fat development. Indeed, it appears that changes in the number and size of adipocytes in the young animal reflect nutritionally-induced differences in body fat, but are not, in themselves, causal factors. Our findings also provide no evidence that nutritional practices in the early postnatal period which stimulate the rapid accumulation of body fat have any long-term effect on the subsequent development of adipose tissue or on body-fat content in later life.

The authors wish to thank Messrs S. Oldfield and W. Chapman for their technical assistance. We also thank Dr R. Martin for his assisiance with the DNA analyses and $\mathrm{Mr}$ R. Jardine for the statistical analysis of the results. This work was supported by a financial grant from the Australian Pig Industry Research Committee.

\section{REFEREN CES}

Agricultural Research Council (1967). Nutrient Requirements of Farm Livestock, No. 3, Pigs. London: Agricultural Research Council.

Bertrand, H. A. \& Masoro, E. J. (1977). Nature, Lond. 266, 62.

Black, J. L. (1974). Proc. Aust. Soc, Anim. Prod. 10, 211.

Braude, R. \& Newport, M. J. (1973). Br. J. Nutr. 29, 447.

Brook, C. G. D. (1972). Lancet ii, 624.

Campbell, R. G. (1981). The influence of nutrition in early life on growth and development in the pig. PhD Thesis, Melbourne University. 
Campbell, R. G. \& Dunkin, A. C. (1980). Proc. Nutr. Soc. Aust. 5, 156.

Duncan, D. B. (1955). Biometrics 11, 1.

Gurr, M. I. \& Kirtland, J. (1978). Int. J. Obesity. 2, 401.

Hirsch, J. \& Knittle, J. L. (1970). Fedn. Proc. Fedn. Am. Socs. exp. Biol. 29, 1516.

Hood, R. L. (1977). Proc. Nutr. Soc. Aust. $2,43$.

Hood, R. L. \& Allen, R. E. (1977), J. Lipid Res. 18, 275.

Kirtland, J. \& Gurr, M. I. (1980). J, agric. Sci., Camb. 95, 325.

Knittle, J. L. (1972). J. Nutr. 102, 427.

Knittle, J. L. \& Hirsch, J. (1968). J. clin. Invest. 47, 2091.

Lee, Y. B., Kauffman, R. G. \& Grummer, R. H. (1973a). J. Anim. Sci. 37, 1312.

Lee, Y. B., Kauffman, R. G. \& Grummer, R. H. (1973b). J. Anim. Sci. 37, 1319.

Martin, R. F. \& Donohue, D. C. (1972). Analyt. Biochem. 47, 562.

Moss, F. P. (1968). Am. J. Anat. 122, 555.

Oscai, L. B., Biblrak, S. P., Dubach, F. B., McGarr, J. A. \& Spirakis, C. N. (1974). Am. J. Physiol. $227,91$.

Oscai, L. B., Spirakis, C. N. \& Wolff, C. A. (1972). J. Lipid Res. 13, 588.

Salans, L. B., Knittle, J. L. \& Hirsch, J. (1968). J. clin. Invest. 47, 153.

Smith, U., Sjostrom, L. \& Bjorntorp, P. (1972). J. Lipid Res. 13, 822.

Williams, I. H. (1976). Nutrition of the young pig in relation to body composition. PhD Thesis, University of Melbourne.

Winick, M. \& Noble, A. (1967). J. Nutr. 91, 179.

Wood, J. D., Enser, M. B. \& Restall, D. J. (1978). Anim. Prod. 27, 1. 